\title{
Regional disparities in financing innovations in small and medium-sized enterprises
}

\author{
Eva Koišová \\ Faculty of Social Economics Relationships, \\ Alexander Dubcek University of Trencin, \\ Slovakia \\ eva.koisova@tnuni.sk

\section{Eva Grmanová} \\ Faculty of Social Economics Relationships, \\ Alexander Dubcek University of Trencin, \\ Slovakia \\ eva.grmanova@tnuni.sk

\section{Jozef Habánik} \\ Faculty of Social Economics Relationships, \\ Alexander Dubcek University of Trencin, \\ Slovakia \\ jozef.habanik@tnuni.sk
}

Abstract. Small and medium-sized enterprises have a strong potential for economic development in Slovak Republic. They play the key role in transfer of technologies and knowledge, thus contribute to transfer of innovations to the market. Therefore, financing innovations is a major prerequisite for successful implementation of innovative business processes. One of the research tasks was to ask business entities to provide their opinions on bank loans to finance innovations, and on transparency of information on bank loan conditions. Next, differences in financing innovations by small and medium-sized enterprises in the regions of Slovak Republic were analysed. Opinions from 541 respondents from all 8 Slovak regions were obtained through a questionnaire survey. A $\chi^{2}$ independence test and a test to compare a percent and a constant were conducted. The research findings confirm there is a correlation between the regions and the use of earnings to finance innovations by small and medium-sized enterprises. Thus, there are regions that differ greatly in whether SMEs finance innovations from their own sources. Moreover, a correlation between the regions and the use of the EU funds to finance innovation in small and medium-sized enterprises was confirmed.

Keywords: small and medium-sized enterprises, innovation, region, Slovak Republic. 
JEL Classification: R58, G21, O16

\section{INTRODUCTION}

The European Commission defines small and medium-sized enterprises as enterprises with fewer than 250 employees and the annual turnover below EUR 50 million (European Commission, 2003). Due to their ability to quickly adapt to changing contexts and high levels of internal flexibility, SMEs are considered to be the driving force of innovation. At the same time, SMEs also face considerable constraints with regard to their access to financial resources and their ability to build up organizational structures (Parker et al., 2009). SMEs play the key role in technology and knowledge transfer and contribute to the transfer of innovations to the market. Cooperation with research institutes, private and public agencies, and universities is considered to be an invaluable source of external knowledge (Kammerer, 2009). Owing to innovative SMEs, the entire sectors have been renewed and new industries established over the past twenty years (Simionescu et al., 2017). Rapidly growing businesses are a must for emerging industries to develop and structural changes to speed up since Europe needs to become a sustainable knowledge-based economy with high-quality jobs.

Undoubtedly, small and medium-sized enterprises represent a strong potential for economic development in Slovak Republic. According to the Slovak Business Agency (2017), the number of SMEs per 100 inhabitants was $7.4 \%$ in 2014, with only $4.6 \%$ in the EU-28. SMEs are also vital in terms of employment. In 2016, the share of SMEs in employment was $74.1 \%$ and also $43.8 \%$. in gross production by the non-financial sectors. Therefore, SMEs are the key for the state when guiding further development of the country (Hiadlovský et al., 2016). Van Hemel and Cramer (2002) highlight that lack of knowledge, awareness and investment are barriers for moving towards sustainable practices and more responsible business in SMEs. The level to which the technological environment is developed has a major impact on the development of society overall. Technological environment encompasses the quality of education, support for science, and use of scientific knowledge in practice. The extent to which technological environment is developed has a direct effect on the pace of country's economic growth (Plchová, 2013). One of the major documents supporting the investment increase in innovation and innovative solutions is the 2020 Strategy by the European Commission. This strategic document also confirmed the Lisbon strategic goal of increasing the share of investment in science, research and innovation to at least $3 \%$ of the GDP of themember countries.

In this regard, enterprises have an active interest in innovations and access to the outcomes of science and research activities. Innovations have become a must for enterprises striving to survive at the market (Lazányi, 2017). Therefore, they have to be focused on applying new systems or ideas that bring changes with them. Product or process innovations are absolutely needed for organizations with any type of strategy and can become significant sources of their competitive advantage (Burciu, 2017; Rudy et al., 2013). A competitive business environment creates conditions for regional development. Balanced entrepreneurial activities in all regions ensure fair and equal allocation of both economic and social capital as well as improvements in the standards of living. The increase in the number of enterprises goes hand in hand with job creation and household income increases. In addition, conditions are provided for science and research support and creation of new innovations. According to the Statistical Yearbook of Slovak Republic (2015), small and medium-sized enterprises accounted for approximately $99.68 \%$ of the total number of enterprises operating in the country back in 2014. From the total number of enterprises, $91.95 \%$ were microenterprises. Regarding small-sized enterprises, they mostly operate in wholesale and services. From the sectoral point of view, the largest representation of medium-sized enterprises was in the industry. This is a clear evidence of the significant role that small and medium-sized enterprises are playing in the development of national 
economy. Their positive growth and enhanced competitiveness make the national economy thrive. Innovations are the core components in positive development of small and medium-sized enterprises. According to the data of the Slovak Business Agency (2015), Slovak small and medium-sized enterprises are lagging behind the EU average (48\%) in innovative activities as only every third SME was active in this area $(30.5 \%)$ in 2014.

The paper provides unique findings,and since no similar studies have been carried out to date, our results cannot be compared with other scientific data. Thus, a questionnaire survey was used to create own database. In the paper, differences in financing SME innovations in the SR regions were analysed in order to identify the regions in which SMEs are focused less on specific types of funding. The questionnaire method was employed in order to obtain relevant data from the sample of 541 respondents, out of 573 in total. The respondents were from all the regions of Slovak Republic. The survey was conducted in the course of 2016 and the NUTS III level (common classification of territorial units for statistics) was employed in the research.

\section{LITERATURE REVIEW}

Any well-functioning economy aims at reducing regional disparities in terms of economic life, standard of living and employment. It is a challenge for most of the countries and especially for the Slovak Republic that is not successful at decreasing regional disparities.

Sound economic development of any society, state or region undoubtedly requires the existence of enterprises and their entrepreneurial activities. Majority of authors researching the issue agree that enterprises and their competitive ability determine the sound development of macroeconomic indicators (Audretsch, 2004; Baumol, 2002; Vojtovič 2016). In this context, small and medium-sized enterprises (SMEs) play a significant role (Burgstaller\& Wagner, 2015, Ayyagari et al., 2007). Competitiveness is closely connected with innovative activities of enterprises, and innovations are becoming a driving force for business entities. Small and medium-sized enterprises (SMEs), in particular, are considered to be the key innovators as they are a significant component in developed economies (e. g. Bruce et al. 2009, Smékalová et al., 2014). In the European Union, $99 \%$ of entrepreneurial activities are performed by small and mediumsized enterprises that provided two-thirds of new jobs (Falkner \& Hiebl, 2015). In times of globalization, regions are also under severe pressure to be competitive. Some authors note (e.g., Akberdina, Tretyakova, \& Vlasov, 2017) that small and medium-sized enterprises are now playing a critical role even in the development of industrial metropolis. Therefore, their development strategies regard the need to strengthen the stability of and support enterprises in creating a competitive environment. By stabilizing its activities, seeking or strengthening its competitive advantage, every single manufacturing enterprise or service provider contribute to the enhancement of competitiveness of the environment in which it operates (Bočáková, 2015; Bobáková, 2017). Vinczeová (2016) argues that the ability to innovate is mainly driven by the innovation potential of enterprises and the entire economy, amount of money spent on research and development by entrepreneurial entities, and the quality of cooperation between scientific and research institutions and business entities.

Several authors address the impact of various factors on small and medium-sized businesses and the impact of innovation on the performance of small and medium-sized enterprises while using various methods of analysis. Testing of statistical hypotheses is a frequently used method (Akinwale, 2018, Virglerova et al. 2017; Kaufmann, 2012; Kljucnikov \& Popesko, 2017). In contrast, some analyses attempt Virglerovato determine the impact that small and medium-sized enterprises have on various socio-economic factors (Straka et al., 2015). 
Small and medium-sized enterprises are more than ever before subject to the competitive pressures of the world economy and huge multinational companies, which can be reduced by expanding a competitive advantage (Krajnakova et al., 2015). The key prerequisites for enterprises and the economy of both regions and the entire country to grow include innovations and research and development activities in enterprises. At the same time, however, SMEs face considerable constraints regarding their access to financial resources and their ability to build organizational structures (Auer \&Jarmai, 2018). Silver, Johanson, and Berggren (2016) place greater focus on the fact that equity investors are shown to have a major influence on entrepreneurial performance, because business owners with an entrepreneurial orientation gain substantially from interaction with investors through the transfer of knowledge. In their study, Pierraskis and Sridaskis (2017) confirm and emphasize the important role that joint investments, be they from public or private funds, play in promoting innovations. Using regional funds to support venture capital in early stages of entrepreneurship can bring a rapid return, and thus to support the private sector (Mason \& Harrison, 2003). Vovchak and Rudevska (2016) emphasize that bank lending maybe one of the main sources of financing for innovation at an enterprise in some countries. Small and medium-sized enterprises, however, view obtaining financial resources and then engaging them in areas of innovations, research and development as a great problem (Tödtling\& Kaufmann, 2001, Müller \& Zimmermann, 2009). The development and growth of the SME sector depend highly on their easy access to financial resources. The issues of entrepreneurial environment and access of SMEs to financial resources were dealt with by Belás et al. (2015) who compared the selected regions in the Czech Republic and Slovakia. Virglerová et al. (2016) addressed the issues of financial risk management in SME segment in the Czech Republic. Being not thoroughly familiar with the conditions under which the banks provide loans to micro-enterprises was found a problem for entrepreneurs in the Czech Republic (Belás et al., 2016). The research work by Fil'a and Kučera (2015) highlights the problem of considerable regional disparities, and distinct circumstances existing in the Bratislava region and the remaining Slovak regions, especially in terms of employment and investments. Metropolitan regions not only in the Slovak Republic but also in many EU Member States seem to be markedly better off. If we assessed the innovative performance of individual regions of Slovakia, the results would be similar to those of other EU28. What is, however, specific of Slovakia, is that the differences are quite big. Fil'a and Kučera (2015) laim that this also applies to the evaluation of the number of research and development staff, as well as investment or total R\&D costs in both corporate and public spheres. The innovation performance of the Slovak regions wasassessed by Ivanová and Masárová (2016). They came to a conclusion that the innovation performance in the Slovak regions is given by the number of expenses on research and development. Moreover, the authors concluded that, in the case of subsidized financing, innovations can reduce regional disparities within the country. Direct foreign investment also plays a significant role. DFI consists of capital, know-how and technology. Popescu (2014) maintains that DFI is a major component of growth in Central and Eastern European countries (SVE), lacking, however, sufficient amount of national funds.

\section{METHODOLOGY}

\subsection{The goal, data and hypotheses}

Financing innovations is a widely discussed topic in the light of the existing and new innovative financing measures in Europe. Effective financing of innovations necessitates all the stakeholders to the innovation process to be engaged (owners, managers, employees) inputting innovations into practice (Bobáková, 2009). Both internal and external resources are used as the core sources of innovation funding. Both external and internal sources of finance are used to finance innovations. The key internal source to 
fund innovations is the business earnings, which gives businesses considerable freedom in decision-making. Nevertheless, external sources of finance are frequently required to fund innovation activities. Regarding external sources, businesses may choose to finance their innovative activities through the state budget funds, EU funds, or different types of loans, including venture capital. When financing innovations through the aforementioned options, financial control over businesses may be lost. Venture capital is being successfully used to fund development in the EU countries, yet, it is paid little attention to in the Slovak economy. More frequent use of venture capital can make it possible to finance mainly innovative business activities (Aernoudt, 2005).

Various regional disparities may exist in the structure of financial resources. Being aware of the can make state policy focus on the better promotion of less used sources of finance, and thus to considerably increase the amount of innovation in SMEs in the Slovak Republic.

The purpose of the paper is to analyse the differences in financing innovations by SMEs in the regions of the SR. Regional disparities in financing innovations by SMEs through business earnings, EU funds, bank loans and other sources. Regional differences will be compared in terms of SMEs' views on the provision of financial assistance to SMEs by the state to enhance their innovative performance.

Traditionally, enterprises are classified into small-sized, medium-sized and large ones. According to the Statistical Office of the Slovak Republic (2017), micro-enterprises have 1 - 9 persons employed, small-sized enterprises have $1-49$ persons employed, medium-sized enterprises have $50-249$ persons employed, and large enterprises have 250 or more persons employed.

A research on the business environment of small and medium-sized enterprises was carried out in 2016. The method of the questionnaire was employed to obtain the relevant data from a sample of 541 respondents, out of 573 in total. The respondents were from all the regions (NUTS III) in the Slovak Republic. The most respondents were from the Žilina region (22.18\%), followed by respondents from the Trenčín region (20.70), Trnava region (13.31\%), Prešov region (10.91\%), Nitra region (10.35\%), Bratislava region (8.13\%), Košice region (7.95\%), BanskáBystrica region (6.47\%). Respondents by the enterprise size were as follows: $55.26 \%$ of respondents were employed in microenterprises, $29.76 \%$ of respondents were employed in small-sized enterprises, and $14.97 \%$ of respondents were employed in medium-sized enterprises. From the sectoral point of view, $19.44 \%$ of respondents worked in manufacturing, $28.15 \%$ of respondents were from trade, $5 \%$ of respondents were from agriculture, $12.96 \%$ of respondents were under construction, $6.5 \%$, of respondents, were from transport and $27.96 \%$ of respondents worked in other sectors (mainly services sector).

By legal forms of business, the structure of respondents was following: $30.68 \%$ of respondents were self-employed persons, $58.41 \%$ of respondents worked in limited liability companies, $8.31 \%$ of respondents worked in joint stock companies and $2.59 \%$ of respondents worked in organizations with other legal forms.

The questionnaire contained 45 questions. The opening questions asked respondents to indicate their business size, duration of their entrepreneurial activity, a region in which respondents operate, a position held in the business, the scope of business, and the legal form of business. In the following part of the questionnaire, respondents were asked to provide their opinions on the defined areas of the entrepreneurial environment, namely the requirements for applying for external sources of finance. A 5- point Likert scale was used (1 - strongly agree, 2 - agree, 3 - neither agree nor disagree, 4 - disagree, 5 - strongly disagree). Bearing in mind the purpose of the paper, selectively closed questions were asked, such as whether SMS used their earnings, EU funds, bank loan, government subsidies, or other options to finance innovations, and whether the state renders assistance to SMEs in enhancing their innovation performance. Questionnaires were personally distributed to respondents in individual regions of the Slovak Republic, then processed and evaluated in Microsoft Excel. Statistical analyses were performed using Statistica software. 


\subsection{Formulation of hypotheses}

It was assumed that the regions do not differ significantly in the likelihood related to employing various sources to finance innovations. The following null hypotheses $\mathrm{H}_{0}$ and alternative hypotheses $\mathrm{H}_{1}$ were stated:

$1 \mathrm{H}_{0}$ : There is no dependence between the regions and the use of earnings to finance innovations in an enterprise.

$1 \mathrm{H}_{1}$ : There is a dependence between the regions and the use of earnings to finance innovations in an enterprise.

$2 \mathrm{H}_{0}$ : There is no dependence between the regions and the use of EU funds to finance innovations in an enterprise.

$2 \mathrm{H}_{1}$ : There is a dependence between the regions and the use of EU funds to finance innovations in an enterprise.

$3 \mathrm{H}_{0}$ : There is no dependence between the regions and the use of bank loans to finance innovations in an enterprise.

$3 \mathrm{H}_{1}$ : There is a dependence between the regions and the use of bank loans to finance innovations in an enterprise.

$4 \mathrm{H}_{0}$ : There is no dependence between the regions and the use of government subsidies to finance innovations in an enterprise.

$4 \mathrm{H}_{1}$ : There is a dependence between the regions and the use of government subsidies to finance innovations in an enterprise.

$5 \mathrm{H}_{0}$ : There is no dependence between the regions and the views of SMEs on whether the state is helpful in increasing their innovative performance.

$5 \mathrm{H}_{1}$ : There is a dependence between the regions and the views of SMEs on whether the state is helpful in increasing their innovative performance.

It follows from the reports on research and development published yearly by the Statistical Office of the SR (2013) that the expenditures on innovations were mostly made through own sources. Therefore, it is assumed that a probability of more than $50 \%$ exists in all the regions that the business innovations are financed through their earnings.

The null hypothesis $6 \mathrm{H}_{0}$ versus the unilateral alternative hypothesis $6 \mathrm{H}_{1}$ is tested.

$6 \mathrm{H}_{0}$ : There is a $50 \%$ probability that SMEs operating in region finance innovations through their own sources.

$6 \mathrm{H}_{1}$ : The probability that SMEs operating in region finance innovations through their own sources is higher than $50 \%$.

\subsection{Research methodology}

To test null hypotheses $1 \mathrm{H}_{0}$ to $5 \mathrm{H}_{0}, \chi^{2}$ independence test was employed. Statistics $\chi^{2}$ was used as a test criterion, which is expressed as follows

$$
\chi^{2}=\sum_{i=1}^{r} \sum_{\mathrm{j}=1}^{\mathrm{s}} \frac{\left(f_{b_{i j}}-f_{e_{i j}}\right)^{2}}{f_{e_{i j}}},
$$

$$
\begin{aligned}
& f_{b_{i j}} \quad \text { denotes the frequency of the observed data, } \\
& f_{e_{i j}} \quad \text { is the frequency of the expected values. }
\end{aligned}
$$

The test is valid if no less than $80 \%$ of the estimated expected cell frequencies are at least 5 and the remaining are at least 1 (Řezanková, 2010). 
The null hypotheses were tested at a significance level of 0.05 . Hypotheses were evaluated was performed using the p-level, which expresses the lowest possible level of significance for the rejection of a null hypothesis. When the p-level is less than or equal to the significance level of 0.05 , the null hypothesis is rejected at the significance level of 0.05 . When the p-level is higher than the significance level of 0.05 , the null hypothesis will not be rejected at the significance level of 0.05 . The statistical software Statistica was utilised to do the evaluation.

In order to test the $6 \mathrm{H}_{0}$ hypothesis, the $\mathrm{U}$ testing statistics will be employed which is expressed as follows:

$$
U=\frac{P-\pi_{0}}{\sqrt{\frac{\pi_{0}\left(1-\pi_{0}\right)}{n}}},
$$

where $\pi_{0}$ denotes a constant, $\mathrm{n}$ denotes a sample size, $\mathrm{P}$ denotes a selective relative frequency. Given that a null hypothesis holds true, $\mathrm{U}$ has an asymptotic standard normalized distribution.

The null hypothesis $\mathrm{H}_{0}: \pi=\pi_{0}$ was tested at the significance level of 0.05 . The evaluation was performed by means of a critical region that, for a one-tailed hypothesis $\mathrm{H}_{1}: \pi>\pi_{0}$, is expressed as

$U>u_{1-a}$ where $u_{1-a}$ is a tabulated critical value of a standard normalized distribution (Pacáková et al. 2003).

\section{EMPIRICAL RESULTS AND DISCUSSION}

The results of testing null hypotheses 1-5 were calculated using Statisticasoftware, and are given in Table 1.

Table 1

Testing null hypotheses $1 \mathrm{H}_{0}-5 \mathrm{H}_{0}$

\begin{tabular}{|l|c|c|c|}
\hline \multicolumn{1}{|c|}{$\begin{array}{c}\text { No dependence exists between the } \\
\text { regions and the fact that }\end{array}$} & Meeting a condition & 象 & P-value \\
\hline $\begin{array}{l}\text {-business earnings were used to finance } \\
\text { innovations }\end{array}$ & Met & 15.3152 & 0.03217 \\
\hline $\begin{array}{l}\text {-EU funds were used to finance } \\
\text { innovations }\end{array}$ & Met & 22.0127 & 0.00253 \\
\hline $\begin{array}{l}\text {-bank loans were used to finance } \\
\text { innovations }\end{array}$ & Not met & 23.9276 & 0.09961 \\
\hline $\begin{array}{l}\text {-government subsidies were used to } \\
\text { finance innovations }\end{array}$ & Not met & 54.5875 & 0.00117 \\
\hline $\begin{array}{l}\text { No dependence exists between the } \\
\text { regions and the views on the state being } \\
\text { helpful in enhancing SMEs innovation } \\
\text { performance }\end{array}$ & & & 0.00191 \\
\hline
\end{tabular}

Source: authors' own calculations in Statistica software

The data listed in Table 1 show that the null hypothesis $1 \mathrm{H}_{0}$ is rejected and an alternative hypothesis $1 \mathrm{H}_{1}$ is accepted. The alternative hypothesis states that there is a dependence between the regions and the use of earnings to finance business innovations. The null hypothesis $2 \mathrm{H}_{0}$ is also rejected and an alternative hypothesis $2 \mathrm{H}_{1}$ is accepted. The alternative hypothesis says that there is a dependence between the regions and the use of EU funds to finance innovations in an enterprise. 
The null hypothesis $3 \mathrm{H}_{0}$ is not rejected. In the case of testing the null hypotheses $4 \mathrm{H}_{0}$ and $5 \mathrm{H}_{0}$, conditions for conducting a $\chi^{2}$ test of independence are not met.

Since the alternative hypothesis $1 \mathrm{H}_{1}$ on the existence of the dependence between the regions and the use of earnings to finance SMEs innovations was accepted, the most frequent addenda used to calculate the resulting $\chi^{2}$ value according (Clauss\& Ebner, 1988) will be identified. Table 2 lists the expected frequencies.

Table 3, the column denoted $(P-O)^{\wedge} 2 / O$ show the addenda to calculate $\chi^{2}$.

Table 2

Expected frequencies - $1 \mathrm{H}_{0}$ testing

\begin{tabular}{|c|c|c|c|c|c|c|c|c|c|}
\hline \multicolumn{2}{|l|}{ Pearson Chi: $15.3152, \mathrm{sv}=7, \mathrm{p}=0.032174$} \\
\hline & KE & PO & ZA & NR & BA & BB & TT & TN & SUM \\
\hline 0 & 17.8041 & 24.4288 & 49.6858 & 23.1867 & 18.2181 & 14.4917 & 29.8115 & 46.3734 & 224.0000 \\
\hline 1 & 25.1959 & 34.5712 & 70.3142 & 32.8133 & 25.7819 & 20.5083 & 42.1885 & 65.6266 & 317.0000 \\
\hline SUM & 43.0000 & 59.0000 & 120.0000 & 56.0000 & 44.0000 & 35.0000 & 72.0000 & 112.0000 & 541.0000 \\
\hline
\end{tabular}

Source: authors' own calculations in Statistica software

$\chi^{2}-1 \mathrm{H}_{0}$ testing

\begin{tabular}{|l|c|c|c|c|}
\hline & $\mathbf{P}$ & $\mathbf{O}$ & $\mathbf{P}-\mathbf{O}$ & $\mathbf{( P - O )}^{\wedge} \mathbf{2} / \mathbf{O}$ \\
\hline Košice Region (KE) & 23.00 & 17.8041 & 5.1959 & 1.51636 \\
\hline Prešov Region (PO) & 31.00 & 24.4288 & 6.5712 & 1.76761 \\
\hline Žilina Region (ZA) & 59.00 & 49.6858 & 9.3142 & 1.74606 \\
\hline Nitra Region (NR) & 20.00 & 23.1867 & -3.1867 & 0.43797 \\
\hline Bratislava Region (BA) & 16.00 & 18.2181 & -2.2181 & 0.27006 \\
\hline BanskáBystrica Region (BB) & 14.00 & 14.4917 & -0.4917 & 0.01668 \\
\hline Trnava Region (TT) & 22.00 & 29.8115 & -7.3734 & 2.04685 \\
\hline Trenčín Region (TN) & 39.00 & 46.3734 & -7.3734 & 1.17238 \\
\hline Košice Region (KE) & 20.00 & 25.1959 & -5.1959 & 1.07150 \\
\hline Prešov Region (PO) & 28.00 & 34.5712 & -6.5712 & 1.24904 \\
\hline Žilina Region (ZA) & 61.00 & 70.3142 & -9.3142 & 1.23381 \\
\hline Nitra Region (NR) & 36.00 & 32.8133 & 3.1670 & 0.30948 \\
\hline Bratislava Region (BA) & 28.00 & 25.7819 & 2.2181 & 0.19083 \\
\hline BanskáBystrica Region (BB) & 21.00 & 20.5083 & 0.4917 & 0.01179 \\
\hline Trnava Region (TT) & 50.00 & 42.1885 & 7.8115 & 1.44635 \\
\hline Trenčín Region (TN) & 73.00 & 65.6266 & 7.3734 & 0.82843 \\
\hline Sum & $\mathbf{5 4 1 . 0 0}$ & $\mathbf{5 4 1 . 0 0 0 0}$ & $\mathbf{0 . 0 0 0 0}$ & $\mathbf{1 5 . 3 1 5 1}$ \\
\hline
\end{tabular}

Source: authors' own calculations in Statistica software

Individual $\chi^{2}$ addenda are given in Table 3. It is obvious that the resulting $\chi^{2}$ value mostly reflects the sums calculated for the Trnava and Prešov regions. Thus, it can be inferred that the difference in frequencies related to the use of SMEs earnings to finance innovations is found in Trnava and Prešov regions. In Trnava 
region, the highest percentage of respondents $(69.44 \%)$ used the business earnings to finance innovations. In the Prešov region, however, only $47.46 \%$ of respondents used the business earnings to finance innovations.

Since the alternative hypothesis $2 \mathrm{H}_{1}$, stating that a dependence exists between the regions and the SMEs use of EU funds to finance their innovations was accepted, the most frequent sums used to calculate the resulting $\chi^{2}$ value will be identified. Table 4 lists the expected frequencies. Table 5 , the column denoted $(P-O)^{\wedge} 2 / O$ show the sums to calculate $\chi^{2}$.

Table 4

Expected frequencies $-2 \mathrm{H}_{0}$ testing

\begin{tabular}{|c|c|c|c|c|c|c|c|c|c|}
\hline \multicolumn{2}{|c|}{ Pearson Chi: $22.0127, \mathrm{sv}=7, \mathrm{p}=0.002529$} \\
\hline & KE & PO & ZA & NR & BA & BB & TT & TN & SUM \\
\hline 0 & 36.8004 & 50.4935 & 102.6987 & 47.9261 & 37.6562 & 29.9538 & 61.6192 & 95.8521 & 463.0000 \\
\hline 1 & 6.1996 & 8.5065 & 17.3013 & 8.0739 & 6.3438 & 5.0462 & 10.3808 & 16.1479 & 78.0000 \\
\hline SUM & 43.0000 & 59.0000 & 120.0000 & 56.0000 & 44.0000 & 35.0000 & 72.0000 & 112.0000 & 541.0000 \\
\hline
\end{tabular}

Source: authors' own elaboration in Statistica software

Table 5

$\chi 2$ - testing $2 \mathrm{H}_{0}$

\begin{tabular}{|l|c|c|c|c|}
\hline & $\mathbf{P}$ & $\mathbf{O}$ & $\mathbf{P - O}$ & $\mathbf{( P - O )}^{\wedge} \mathbf{2} / \mathbf{O}$ \\
\hline Košice Region (KE) & 31.00 & 36.8003 & -5.80030 & 0.91422 \\
\hline Prešov Region (PO) & 46.00 & 50.4935 & -4.49350 & 0.39988 \\
\hline Žilina Region (ZA) & 109.00 & 102.6987 & 6.30130 & 0.38663 \\
\hline Nitra Region (NR) & 49.00 & 47.9261 & 1.07390 & 0.02406 \\
\hline Bratislava Region (BA) & 37.00 & 37.6562 & -0.65620 & 0.01143 \\
\hline BanskáBystrica Region (BB) & 26.00 & 29.9538 & -3.95380 & 0.52189 \\
\hline Trnava Region (TT) & 60.00 & 61.6192 & -1.61920 & 0.04255 \\
\hline Trenč́́n Region (TN) & 105.00 & 95.8521 & 9.14790 & 0.87305 \\
\hline Košice Region (KE) & 12.00 & 6.1996 & 5.80040 & 5.42690 \\
\hline Prešov Region (PO) & 13.00 & 8.5065 & 4.49350 & 2.37366 \\
\hline Žilina Region (ZA) & 11.00 & 17.3013 & -6.30130 & 2.29499 \\
\hline Nitra Region (NR) & 7.00 & 8.0739 & -1.07390 & 0.14284 \\
\hline Bratislava Region (BA) & 7.00 & 6.3438 & 0.65620 & 00.06788 \\
\hline BanskáBystrica Region (BB) & 9.00 & 5.0462 & 3.95380 & 3.09788 \\
\hline Trnava Region (TT) & 12.00 & 10.3808 & 1.61920 & 0.25256 \\
\hline Trenčín Region (TN) & 7.00 & 16.1479 & -9.14790 & 5.18235 \\
\hline Sum & 541.00 & 540.0000 & 0.00010 & 22.01279 \\
\hline
\end{tabular}

Source: authors' own elaboration in Statistica software

Individual $\chi^{2}$ sums are given in Table 5. It is evident that the resulting $\chi^{2}$ value mostly reflects the sums calculated for the Košice and Trenčín regions. Thus, it can be inferred that the difference in frequencies related to the use of EU funds to finance innovations is found in Košice and Trenčín regions. In Košice region, the highest percentage of respondents $(27.91 \%)$ used EU funds to finance their innovations. In Trenčín region, however, only $6.25 \%$ of respondents used EU funds to finance their innovations. 
Number of SMEs financing innovations through their earnings

\begin{tabular}{|c|c|c|c|}
\hline & 0 & 1 & SUM \\
\hline \multirow{2}{*}{$\mathrm{KE}$} & 23 & 20 & 43 \\
\hline & $53.49 \%$ & $46.51 \%$ & \\
\hline \multirow{2}{*}{ PO } & 31 & 28 & 59 \\
\hline & $52.54 \%$ & $47.46 \%$ & \\
\hline \multirow{2}{*}{$\mathrm{ZA}$} & 59 & 61 & 120 \\
\hline & $49.17 \%$ & $50.83 \%$ & \\
\hline \multirow{2}{*}{ NR } & 20 & 36 & 56 \\
\hline & $35.71 \%$ & $64.29 \%$ & \\
\hline \multirow{2}{*}{ BA } & 16 & 28 & 44 \\
\hline & $36.36 \%$ & $63.64 \%$ & \\
\hline \multirow{2}{*}{ BB } & 14 & 21 & 35 \\
\hline & $40 \%$ & $60 \%$ & \\
\hline \multirow{2}{*}{$\mathbf{T T}$} & 22 & 50 & 72 \\
\hline & $30.56 \%$ & $69.44 \%$ & \\
\hline \multirow{2}{*}{$\mathbf{T N}$} & 39 & 73 & 112 \\
\hline & $38.42 \%$ & $65.18 \%$ & \\
\hline SUM & 224 & 317 & 541 \\
\hline
\end{tabular}

Source: authors' own elaboration in Statistica software

The hypothesis $6 \mathrm{H} 0$ was tested for all the regions in the SR. The $\mathrm{U}$ testing statistics values are given in Table 7. The null hypothesis at the significance level of 0.05 was rejected and an alternative hypothesis in four regions, namely Nitra region, Bratislava region, Trnava region and Trenčín region was accepted. Therefore, a hypothesis saying that there is more than a 50\% probability that SMEs innovations in a region are financed from internal sources was accepted.

Testing null hypothesis $6 \mathrm{H}_{0}$

\begin{tabular}{|l|c|c|}
\hline \multicolumn{1}{|c|}{ Region } & U Testing Statistics & Testing Result \\
\hline Košice Region (KE) & -0.4577 & $\mathrm{H}_{0}$ not rejected \\
\hline Prešov Region (PO) & -0.3902 & $\mathrm{H}_{0}$ not rejected \\
\hline Žilina Region (ZA) & 0.1818 & $\mathrm{H}_{0}$ not rejected \\
\hline Nitra Region (NR) & 2.1387 & $\mathrm{H}_{1}$ accepted \\
\hline Bratislava Region (BA) & 1.8096 & $\mathrm{H}_{1}$ accepted \\
\hline BanskáBystrica Region (BB) & 1.1832 & $\mathrm{H}_{0}$ not rejected \\
\hline TrnavaRegion (TT) & 3.2991 & $\mathrm{H}_{1}$ accepted \\
\hline TrenčínRegion (TN) & 3.2130 & $\mathrm{H}_{1}$ accepted \\
\hline
\end{tabular}

Source: authors' own elaboration in Statistica software

It follows from the aforementioned that regional differences do exist in financing innovations through internal sources of finance and EU funds. Further research should identify and examine what the main causes of regional differences are. Regional differences are also obvious in the assumption that the probability of financing innovations from internal sources is higher than $50 \%$.

\section{CONCLUSION}

The problem that SMEs are generally facing is not a lack of financial sources, but that of understanding on how to obtain the sources. Decisions related to funding options affect businesses throughout their 
existence. If entrepreneurs are to succeed, the right choice regarding the right source of finance is as important as choosing the areas of business and investment.

The relevant statistical data do not include information on the SMEs use of financial sources to fund innovations in the regions of the Slovak Republic. Since our assumptions and subsequent analyses could not be compared with any data, our research is unique in this respect. Several key conclusions were drawn from the research data. In particular, it was confirmed that a dependence exists between the regions and use of earnings to finance innovations in small and medium-sized enterprises. Striking differences were found across the regions in the Slovak Republic as to SMEs financing innovations through their internal sources. In Trnava region, the highest percentage of respondents (69.44\%) use the business earnings to finance innovations. In Prešov region, however, only $47.46 \%$ of respondents used the business earnings to finance innovations.

Moreover, it was confirmed that a dependence exists between the regions and the SMEs use of EU funds to finance their innovations. In Košice region, the highest percentage of respondents $(27.91 \%)$ use EU funds to finance their innovations. In Trenčín region, however, only $6.25 \%$ of respondents (enterprises) use EU funds to finance their innovations.

It was found that in Nitra, Bratislava, Trnava and Trenčín regions, the probability that SMEs finance their innovations through their own sources exceeds $50 \%$.

Bearing in mind the research results, and pursuing even development of the regions and the reduction of regional disparities, it would be advisable to increase the SMEs awareness of the EU funding options to finance innovations, especially in Trenčín region. It is also advisable to enhance the awareness of using external sources of finance through promotional activities in Nitra, Trnava and Bratislava regions. With regard to the aforementioned, we recommend simplifying the conditions under which it is possible to obtain these funds, in particular, to reduce bureaucratic requirements, which, in many cases dissuade enterprises from applying for such funds. Since SMEs often dispose of limited financial resources, they may apply for EU funds or state institutions funds, provided for instance by the Slovak Business Agency (NARMSP), Slovak Guarantee and Development Bank (SZRB) or Eximbanka SR.

We are aware that our research has some limitations as we only focused on identifying regional differences in SME financing. No wider context was taken into consideration, and neither causes nor effects of these changes were addressed. The sample of respondents was large enough and randomly chosen. Nevertheless, we believe that our research is a contribution to the given field as it provides findings which are not collected in statistical surveys. Last but not least, our research has laid a solid foundation for further exploration of these areas.

\section{ACKNOWLEDGEMENT}

The paper is the part of the output of project VEGA 1/0233/16 "Dimensions and factors related to social and economic development of V4 regions". Authors would like to thank to all partners of this research for their cooperation. We would like to thank also Alexander Dubcek University of Trencin, for favourable conditions creation for our research.

\section{REFERENCES}

Akberdina, V., Tretyakova, O., \& Vlasov, A. (2017). A methodological approach to forecasting spatial distribution ofworkplaces in an industrial metropolis. Problems and Perspectives in Management, 15(4), 50-61. doi:10.21511/ppm.15(4).2017.05 
Aernoudt, R. (2005). Business Angels: The Smartest Money for Starters? Plea for a Renewed Policy Focus on Business Angels. International Journal of Business. SSRN papers, 10(3). Retrieved from http://papers.ssrn.com/sol3/papers.cfm?abstract_id=778426

Akinwale, Y., O. (2018). Empirical Analysis of Inbound Open Innovation and Small and Medium-sized Enterprises' Performance: Evidence from Oil and Gas Industry. South African Journal of Economic and Management Sciences. 21(1), 1-9. Retrieved from https://doi.org/10.4102/sajems.v21i1.1608

Audretsch, D. B. (2004). Sustaining Innovation and Growth: Public Policy Support for Entrepreneurship. Industry and Innovation. 11(3), 167-191. Retrieved from http://dx.doi.org/10.1080/1366271 042000265366

Auer, A. \&Jarmai, K. (2018). Implementing Responsible Research and Innovation Practices in SMEs: Insights into Drivers and Barriers from the Austrian Medical Device Sector. Sustainability, 10, 17. Retrieved from https://doi.org/10.3390/su10010017

Ayyagari, M. \& Beck, T. (2007). Demirguc-Kunt, A. "Small and medium enterprises across the globe". Small Business Economics, 29(4), 415-434.

Baumol, W. J. (2002). Free-Market Innovation Machine: Analysing the Growth Miracle of Capitalism. Princeton: Princeton University Press.

Belás, J., Demjan, V., Habánik, J., Hudáková, M. \& Sipko, J. (2015). The business environment of Small and mediumsized companies in selected regions of the Czech Republic and Slovakia. E+M. Ekonomie a Management, 18(1), 95-110.

Belás, J., Vojtovič, S. \& Ključnikov, A. (2016). Microenterprises and Significant Risk Factors in Loan Process. Economics and Sociology, 9(1), 43-59. doi:10.14254/2071-789X.2016/9-1/3

Burciu, A. (2017). Technology and labour market in the European Union. Economics, Management and Sustainability, 2(1), 36-42. doi:10.14254/jems.2017.2-1.3

Bobáková, V. (2009). Niektoré možnosti financovania inovácií. Economic Review, 39(3), 439-447.

Bobáková, V. (2017). The formation of regional self-government in the Slovak Republic and its sources of funding. Administratie si Management Public, (28), 97-115.

Bočáková, N. (2015) Fuzzy logic to support of investments in Research and Development in Small and Medium Sized Businesses. Economics and Sociology, 7(3), 18-29.

Bruce, D., Deskins, J. A., Hill, B. C. \&Rork, J. C. (2009). Small Business Activity and State Economic Growth: Does Size Matter?. Regional Studies, 43(2), 229-245. Retrieved from http://dx.doi. org/10.1080/00343400701808915

Burgstaller, J. \& Wagner, E. (2015). How do family ownership and founder management affect capital structure decisions and adjustment of SMEs? Evidence from a bank-based economy. The Journal of Risk Finance, 16(1).

Clauss, G. \& Ebner, H. (1988). Základy štatistiky pre psychológov, pedagógov a sociológov. Bratislava: SPN.

European Commission. Commission Recommendation of 6 May 2003 Concerning the Definition of Micro, Small and Medium-Sized Enterprises; European Commission Publications Office: Brussels, Belgium. Retrieved December 20, 2017 from http:/ / eur-lex.europa.eu/legal-content/EN/TXT/?uri=CELEX:32003H0361.

European Commission. (2010). Communication from the Commission to the European Parliament, the Council, the European Economic and Social Committee and the Committee of the Regions. Europe 2020 Flagship Initiative Innovation Union. Brussels, 6.10.2010 COM(2010) 546 final.

Falkner, E. M. \& Hiebl, M., R.W. (2015). Risk management in SMEs: a systematic review of available evidence. The Journal of Risk Finance, 16(2), 122-144. Retrieved from https://doi.org/10.1108/JRF-06-2014-0079

Fila, M. \& Kučera, J. (2015). Innovation Performance of the Slovak Republic and its Regional Disparities. In: Innovation Management and Corporate Sustainability. IMACS 2015, 39-51. Retrieved from http://imacs.vse.cz/wpcontent/uploads/2015/08/Proceedings-IMACS-2015-full-papers-APA.pdf\#page $=42$

Hiadlovský, V., Rybovičová, I. \& Vinczeová, M. (2016). Importance of Liquidity Analysis in the Process of Financial Management of Companies Operating in the Tourism Sector in Slovakia. International Journal for Quality Research, 10(10), 779-812.

Ivanová, E. \& Masárová J. (2016). Assessment of innovation performance of Slovak regions. Journal of International Studies, 9(2), 207-218. DOI: 10.14254/2071-8330.2016/9-2/16

Kammerer, D. (2009). The effects of customer benefit and regulation on environmental product innovation: Empirical evidence from appliance manufacturers in Germany. Ecol. Econ, 68(8-9), 2285-2295.

Kaufmann, H., R., Tsangar, H. \& Vrontis, D. (2012). Innovativeness of European SMEs: Mission not yet accompished. Ekonomska Istrazivanja-Economic Research, 25(1), 51-72. DOI: 10.1080/1331677X.2012.11517511 
Kljucnikov, A. \&Popesko, B. (2017). Export and its Financing in the SME Segment. Case Study from Slovakia. Journal of Competitiveness, 9(1), 20-35. DOI: 10.7441/joc.2017.01.02.

Krajnakova, E., Navikaite, A. \&Navickas, V. (2015). Paradigm shift of small and medium-sized enterprises competitive advantage to management of customer satisfaction, Engineering Economics, 26(3), 327-332.

Lazányi, K. (2017). Innovation: The role of trust. Serbian Journal of Management, 12(2), 329-341.

Mason, C. \& Harrison, R. (2003). Closing the Regional Equity Gap? A Critique of the Department of Trade and Industry's Regional Venture Capital Funds Initiative. Reg. Stud., 37(8), 855-868.

Müller, E. \& Zimmermann, V. (2009). The Importance of Equity Finance for R\&D Activity. Small Business Economics. 33(3), 303-318. Retrieved from http://dx.doi.org/10.1007/s11187-008-9098-x

Pacáková, V. et al. (2003). Statistics for Economists. Bratislava: IURA EDITION, 358 p.

Parker, C.M., Redmond, J. \& Simpson, M. (2009). A review of interventions to encourage SMEs to make environmental improvements. Environment and Planning. C: Politics and Space, 27, 279-301.

Pierraskis, Y. \&Sridaskis, G. (2017). Do publicly backed venture capital investments promote innovation? Differences between privately and publicly backed funds in the UK venture capital market. Journal of Business Venturing Insights, 7, 55-64.

Plchová, J. (2013). Základy podnikania. Bratislava: Slovenská technická univerzita v Bratislave, 97 p.

Popescu, G. H. (2014). FDI and Economic Growth in Central and Eastern Europe. Sustainability, 6, 8149-8163.

Rezanková, H. (2010). Analýza dat z dotazníkových šetrené. Praha: Professional Publishing.

Rudy, J. et al. (2013). Manažment a organizačné správanie. Münster: Verlag-Haus Monsenstein und Vannerdat, p. 342.

Silver, L., Johanson, M. \& Berggren, B. (2016). Entrepreneurial orientation, control aversion and performance in SMEs: the contribution of equity investors. Problems and Perspectives in Management, 14(3), 55-64. doi: $10.21511 / \mathrm{ppm} .14(3) .2016 .05$

Simionescu, M., Lazányi, K., Sopková, G., Dobeš, K., \&Balcerzak, A. P. (2017). Determinants of economic growth in V4 Countries and Romania. Journal of Competitiveness, 9(1), 103-116.

Slovak Business Agency. (2017). Malé a strednépodnikanie v č́slach v roku 2016. Bratislava. Retrieved from http://www.sbagency.sk/sites/default/files/image/msp v cislach v roku 2016 final v 20102017002. pdf

Slovak Business Agency. (2016). Malé a strednépodnikanie v cóslach v roku 2015. Bratislava. Retrieved from http://www.sbagency.sk/sites/default/files/msp v cislach v roku 2015 0.pdf

Smékalová, L., Hájek, O., Belás, J. \&Macháček, J. (2014). Perception of Small and Medium Entrepreneurship in the Czech Republic. Journal of Competitiveness, 6(4), 41-49, December 2014 ISSN 1804-171X (Print), ISSN 1804-1728 (On-line), DOI: 10.7441/joc.2014.04.03.

Straka, J., Birčiaková, N. \&Stávková, J. (2015). Impact of SMEs on Standards of Living of Czech Rural Households. Economics \& Sociology, 8(4), 51-64. DOI: 10.14254/2071-789X.2015/8-4/4

ŠÚ SR (2013). Správa o výsledkoch štatistického zist'ovania údajov o výskumno-vývojovom potenciáli SR. 2013

ŠÚ SR. (2015). Štatistická ročenka Slovenskej republiky.

ŠÚ SR. (2017). Metodicképokyny. Retrieved from http://www.statistics.sk/pls/ elisw/utlData.htmlBodyWin?uic=74.

Tödtling, F. \& Kaufmann, A. (2001). The Role of the Region for Innovation Activities of SMEs. European Urban and Regional Studies, 8(3), 203-215. Retrieved from http://dx.doi.org/10.1177/0969776 40100800303.

Van Hemel, C. \& Cramer, J. (2002). Barriers and stimuli for ecodesign in SMEs. J. Clean. Prod, 10, 439-453.

Vinczeová, M. (2016). Zdroje financovania inovačnej činnosti malých a stredných podnikov v Slovenskej republike a vo svete. In: Klúčové faktory inovačnej činnosti malých a stredných podnikov v SR. Zborník vedeckéch statí VEGA 1/0494/15. UMB.

Virglerova, Z., Dobes, K., Kramolis, J. \&Kotaskova, A. (2017). The Influence of SME Owners Education on their Perception of Business Environmnet in Czech Republic. Economics \& Sociology, 10(3), 321-332. DOI: 10.14254/2071-789X.2017/10-3/22

Virglerová, Z., Kozubíková, L., \& Vojtovič, S. (2016). Influence of selected factors on financial risk management in SMEs in the Czech Republic. In: Montenegrin Journal of Economics, 12(1), 21-36.

Vojtovič, S. (2016). The Impact of Emigration on Unemployment in Slovakia. Engineering Economics, 24(3), $207-216$. http://dx.doi.org/10.5755/j01.ee.24.3.3173

Vovchak, O., \& Rudevska, V. (2016). Banking crediting of enterprises' innovation activity in Ukraine. Banks and Bank Systems, 11(4), 97-101. doi:10.21511/bbs.11(4).2016.10 